\title{
Adaptation to Resources and Environments during the Last Glacial Maximum by Hunter-Gatherer Societies in Atlantic Europe
}

\author{
Thierry Aubry and Luís Luís \\ Côa Parque, Fundação para a Salvaguarda e Valorização do Vale do Côa, Rua do Museu, 5150- \\ 610 Vila Nova de Foz Côa, Portugal. Email: thaubry@sapo.pt
}

Javier Mangado Llach

Departament de Prehistòria, Història Antiga i Arqueologia, Facultat de Geografia i Història, Universitat de Barcelona, Spain

Henrique Matias

UNIARQ, Centro de Arqueologia, Universidade de Lisboa, Portugal

KEY WORDS: Solutrean; Raw material supply; Social networks, Creuse Valley; Côa Valley, Síco Massif

Solutrean culture has been interpreted as a response to the Last Glacial Maximum in western Europe. However, to establish a link depends of our knowledge of the impact of global climatic changes at a local level and of the differential preservation and significance of the record. The identification of lithic sources, technology, function, and place of discard, is an effective way to mitigate some of these biases and to improve our understanding of hunter-gatherer societies.

We present the results of a study of flint materials found in several rockshelters and openair sites preserving Upper Solutrean lithic assemblages from France and Portugal, using a Geographic Information System. The network defined by a least-cost algorithm is considered a proxy for social and territoriality reconstruction.

Our goal is to identify recurrences and differences in Solutrean raw material network and management as compared with Middle Paleolithic and Upper Paleolithic assemblages in the same areas, considering environmental changes.

MANY ASPECTS OF VARIATION in hunter-gatherer socioeconomics are closely constrained by environmental factors such as the patterning of exploitable resources. Human behavioral ecology provides one suitable framework from which researchers gain an understanding of the covariation of hunter-gatherer lifeways and environmental factors through comparative ethnographic datasets (e.g., Kelly 1995), which have in turn, heavily influenced archaeological interpretations of hunter-gatherers (e.g., Banks et al. 2009; Binford 2001). We argue that such frameworks are particularly useful for understanding hunter-gatherer settlement systems and subsistence technology as cultural adaptations to the environmental pressures of the Last Glacial Maximum (LGM). Traditionally, analyses that use a similar theoretical framework examine the distribution of sites and tool typologies to identify geographically defined groups with relatively high population densities (Straus 2012). More recently, an ecological perspective known as Environmental Niche Modeling (Elith and Leathwick 2009) has influenced the study of past and present hunter-gatherer societies. This modeling perspective uses the species distribution and environmental data to predict present, future, or past distributions of the species of interest. 
Similarly, Eco-Cultural Niche Modeling (Banks et al. 2009) uses knowledge of environmental constraints affecting human foragers to reconstruct ecological niches exploited by past human populations. The approach combines paleoclimatic data from both oceanic and terrestrial environments with archaeological site information to identify the degree to which regional cultural variability reflects covariation in material culture and ecology. The main criticism of studies using an exclusively ecological perspective for the analysis of human behavioral adaptations is that, besides the basic environmental constraints that all societies face, humans have a unique ability to produce cultural solutions that mediate their relation with the environment. It is the material correlates of such cultural solutions that are the actual subjects of archaeological analysis. Therefore, we recognize that "human interaction with the environment is not the foundation of human society, nor is it a theoretical panacea" (Kelly 1995:36).

On the other hand, the use of ecological modeling to understand the past is based on strong inferences from environmental modeling that is not specifically dependent on archaeological information. Some of the ecogeographic approaches take into account global climatic millennial oscillations but are performed at a multimillennial cultural attribution scale, which privileges the karstic archaeological record (Schmidt et al. 2012). Models aiming to understand how LGM forager groups responded to climatic and environmental variability do not consider the exact correlation between the cold events and stadials and the time lags between when they occurred at various latitudes along the Atlantic coast (Sanchez Goñi and Harrison 2010). Moreover, the exact impact of Heinrich Events (and Stadials) on terrestrial systems and the open-air sedimentary record is still not clearly established. In particular, studies focusing on western Iberia reveal that the preservation of the cave and rockshelter record is directly affected by sea level, karstic system circulation, and related vegetation changes during Heinrich 4 and 3 (Angelucci 2002; Aubry et al. 2011).

Based on the archaeological record, and the complexity involved in the shaping of some of the Solutrean foliate points (namely the large laurel leaves), it has been proposed that the technological investment and knowledge of raw material sources needed to manufacture such tools could be related to a specific hunting strategy and high mobility during the LGM, which in turn promoted an increased level of contact between distant groups (Pelegrin 2007).

Considering that raw material sourcing is an effective way to reconstruct foraging strategies and the ranges involved in resource exploitation (Larick 1984), our aim is to analyze the adaptations of the human societies during the LGM as they relate to lithic raw material supply networks during the Upper Solutrean (22,500 to 23,500 cal BP) in two major regions of Atlantic Europe. A chronocultural, comparative framework is also established through the analysis of Middle and Upper Paleolithic phases in the same areas and makes it possible to examine similarities and differences within and among different climatic phases and cultures. This approach will be based on direct archaeological and geological studies of raw material sources. By identifying sources, we can infer spatial relationships between different geographical areas as well as define ranges and networks. Although the problem of unknown or depleted (and therefore possibly unrecognizable) sources, or the methodological limitations inherent in the characterization and environment of siliceous rocks (Aubry 2005), cannot be ignored, we can still be certain that raw materials were transported from point or area A (source) to a point B (discard location). The reconstruction of the exact means by which a lithic industry was displaced is difficult, perhaps impossible. Despite difficulties, the data nevertheless define a network of points that represent geological sources and archaeological sites (nodes), are linked by "edges" (the lines between source and discard locations; Easley and Kleinberg 2010), and define socioeconomic relationships. Our goals are to (1) establish potential areas of raw material exploitation by hunter-gatherers through the identification of sources in the archaeological record and through comparison with geological resource areas; (2) reconstruct the evolution of 
exploited sources and territories through time and determine whether recurrent synchronic and diachronic patterns exist; and (3) determine if there is a direct correlation between environmental changes and raw material supply patterns.

\section{MATERIALS AND METHODS}

For the past 20 years, our ongoing study has applied a methodology is based primarily on data acquired through archaeological excavation of Solutrean sites, the identification of coherent taphonomically and archaeostratigraphically delineated lithic assemblages, and the analysis of these remains. The lithic raw materials are described macroscopically and classified into categories using petrographic methods (Aubry, Luís et al. 2012b; Aubry, Mangado, and Matias 2014; Fernandes et al. 2008; Mangado 2002; Seronie-Vivien and Seronie-Vivien 1987). This characterization informs the geological survey since it suggests the formation environment of siliceous rocks (pedological, lacustrine, and oceanic) of some of the raw material types. However, the level of detail required is usually absent from geological literature and mapping. Therefore, extensive field survey is required to identify the specific geological formations, even at the outcrop level, and to distinguish primary from secondary positions. The geologic samples are analyzed following the same methodology as the archaeological material.

Once the nodes of the network are defined, the edges (i.e., the links between sources and discard areas) can be defined in two ways. Generally, they are defined through Euclidean geometry, by tracing direct lines between both points (Demars 1982; Féblot-Augustins 1997). However, since movement is constrained by geography, we have used least-cost path analysis to define links between points of the network, bearing in mind that, even though it is closer to the likely actual route of movement, the known limitations of the method (resolution of the Digital Elevation Model and a wide variety of algorithms) and unknown variables (vegetation and cultural constraints to movement, river fords, etc.) present limits to this analysis. In the present study we have produced least-cost paths on SRTM 90 DEM (Jarvis et al. 2008) for the Claise Valley and the Portuguese sites, and on a 100-m reclassification of GEBCO DEM (Becker et al. 2009) for the sites outside these areas. All least-cost paths were determined with an anisotropic time model (Tobler 1993) using the method described by Matsumoto (2008). These networks define pathways used and land-use ranges. Our interpretation is also dependent on the concept of the chaine opératoire, which determines how each category of raw material arrived on site and how it was transformed before being discarded or taken to another site (Pelegrin et al. 1988). In order to define a paleoclimatic influence on the range of the spatial networks, data are correlated with the Greenland ice core climate proxy record (GRIP, Johnsen et al. 2001) plotted on the SFCP2004 time scale of Shackleton et al. (2004).

Our study concerns two major areas of the Upper Solutrean geographical range across Atlantic Europe (Figure 1). The first one corresponds to the lower part of the Creuse Valley basin, one of the northernmost Solutrean site concentrations. From its geological context at the southern margin of the Parisian Basin, it is characterized by a wide variety of Mesozoic and Cenozoic lithostratigraphic units, bearing a large quantity and variety of high-quality flint (Aubry 1991). The second area is at the southeastern limit of the Solutrean range and is divided in two sub-areas. One is located in the West Portuguese Meso-Cenozoic border geological unit and in the Northern Portuguese Estremadura geographical entity, with abundant but low-quality flint nodules (Aubry, Neves, et al. 2008; Aubry, Mangado, and Matias 2014). The other, located in the lower portion of the Côa Valley, in the western limit of the Iberian Meseta, corresponds to the Iberian Hercynian crystalline basement, with no locally available flint sources (Aubry, ed. 2009; Mangado 2002). 


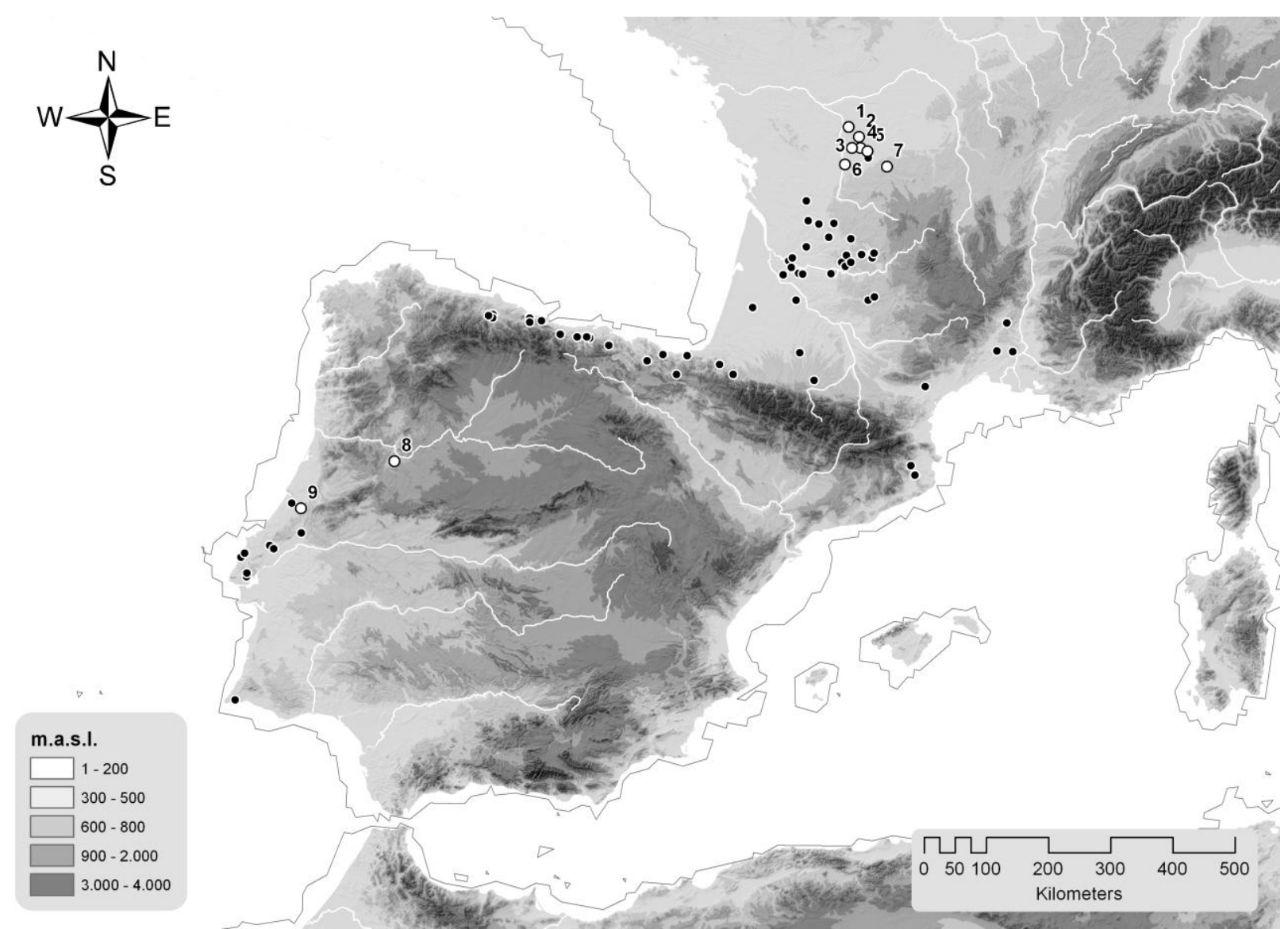

Figure 1. Location of Upper Solutrean sites with lithic assemblages analyzed in this study (white dots) and sites with Franco-Cantabrian shouldered points and large laurel-leaf points (black dots). Basemap: SRTM (present-day meters above sea level) showing approximate LGM coastline.

1. les Roches d'Abilly; 2. les Maîtreaux; 3. la Guittière; 4. Abri Fritsch; 5. les Riaux; 6. la Tannerie;

7. Fressignes; 8. Olga Grande 4; 9. Buraca Grande

\section{NORTHERN TERRITORIES}

Several Solutrean sites are known in the Vienne Valley and its tributary, the Creuse. Attribution is based on the typological assemblages and a few radiometric dates (Table 1). The sequence begins with a phase characterized by small laurel leaves and unifacial points (Allain 1989; Aubry et al. 2007; Smith 1966). The Upper Solutrean is better known, both in open-air sites and caves or rockshelters (Allain 1989; Aubry 1991; Aubry et al. 2007a; Trotignon et al. 1984; Vialou and Vilhena 2012). The Maitreaux open-air site, located near an outcrop of large flint nodules, illustrates raw material management from its sources to its different destinations and the context of the use of lithic assemblages during this period. The site is dated to 19,000 BP by a red deer antler in layer F at Abri Bordes-Fitte at les Roches d'Abilly (Aubry, Dimuccio, et al. 2012) and a charred bone in layer 8d at Abri Fritsch (Trotignon et al. 1984). Refitting and spatial analysis of the lithic remains recovered at Maitreaux define several short-term occupation levels with assemblages characterized by the production of B-type shouldered points (Plisson and Geneste 1984), backed bladelets, and both small and very large laurel leaves (Aubry et al. 1998, 2007a; Aubry, Bradley, et al. 2008). 
Table 1. Upper Solutrean lithic assemblages analyzed in this study.

\begin{tabular}{|c|c|c|c|c|c|c|c|c|c|c|c|}
\hline Site & Site type & Country & Long & Lat. & Layer & Material & $\begin{array}{l}\text { Dating } \\
\text { method }\end{array}$ & Lab Ref. & Age (yr BP) & ${ }^{14} \mathrm{C}$ calBP ${ }^{\mathrm{a}}$ & Reference \\
\hline \multirow[t]{3}{*}{ Bordes-Fitte } & \multirow[t]{3}{*}{$\begin{array}{l}\text { Rock- } \\
\text { shelter }\end{array}$} & \multirow[t]{3}{*}{ France } & \multirow[t]{3}{*}{0.70} & \multirow[t]{3}{*}{$\begin{array}{r}46.9 \\
5\end{array}$} & \multirow[t]{3}{*}{$\mathrm{F}$} & antler & ${ }^{14} \mathrm{C}$ AMS & OxA-22315 & $19,020 \pm 110$ & $\begin{array}{l}23,262-22,255 \\
(95.4 \%)\end{array}$ & Aubry et al. 2012 \\
\hline & & & & & & quartz & OSL & 92203 & $22,000 \pm 1300$ & - & Aubry et al. 2014 \\
\hline & & & & & & feldspar & OSL & 92203 & $24,900 \pm 1200$ & - & Aubry et al. 2014 \\
\hline Fressignes & Open-air & France & 1.61 & $\begin{array}{r}46.4 \\
4\end{array}$ & 2 & - & Typology & - & - & - & $\begin{array}{l}\text { Vialou and Vilhena } \\
2012\end{array}$ \\
\hline Fritsh & $\begin{array}{l}\text { Rock- } \\
\text { shelter }\end{array}$ & France & 1.00 & $\begin{array}{r}46.6 \\
7\end{array}$ & $8 d$ & $\begin{array}{l}\text { charred } \\
\text { bone }\end{array}$ & ${ }^{14} \mathrm{C}$ & GrN 5499 & $19,180 \pm 230$ & - & Trotignon et al. 1984 \\
\hline les Maîtreaux & Open-air & France & 0.94 & $\begin{array}{r}46.8 \\
2\end{array}$ & 2 & - & Typology & - & - & - & Aubry et al. 1998 \\
\hline les Riaux & Open-air & France & 1.16 & $\begin{array}{r}46.6 \\
3\end{array}$ & $\begin{array}{l}\text { Surfac } \\
\mathrm{e}\end{array}$ & - & Typology & - & - & - & Aubry et al. 2003 \\
\hline la Guittière & Cave & France & 0.83 & $\begin{array}{r}46.6 \\
5\end{array}$ & $\begin{array}{l}\text { Surfac } \\
\mathrm{e}\end{array}$ & - & Typology & - & - & - & Patte 1944 \\
\hline la Tannerie & Cave & France & 0.73 & $\begin{array}{r}46.4 \\
0\end{array}$ & - & - & Typology & - & - & - & Pradel 1950 \\
\hline Cardina 1 & Open-air & Portugal & $\begin{array}{r}-7.1 \\
0\end{array}$ & $\begin{array}{r}40.9 \\
7\end{array}$ & 4,10 & quartzite & TL & Gif CAR 5 & $20,700 \pm 1300$ & - & Valladas et al. 2001 \\
\hline Fariseu & Open-air & Portugal & $\begin{array}{r}-7.1 \\
1\end{array}$ & $\begin{array}{r}41.0 \\
3\end{array}$ & 9 & charcoal & ${ }^{14} \mathrm{C}$ AMS & GrA-40167 & $19,020 \pm 80$ & $\begin{array}{l}23,175-22,595 \\
(95,4 \%)\end{array}$ & Aubry 2009 \\
\hline Olga Grande 14 & Open-air & Portugal & $\begin{array}{r}-7.0 \\
5\end{array}$ & $\begin{array}{r}40.9 \\
6\end{array}$ & $2 b$ & - & Typology & - & - & - & Aubry 2009 \\
\hline Olga Grande 4 & Open-air & Portugal & $\begin{array}{r}-7.0 \\
5 \\
\end{array}$ & $\begin{array}{r}40.9 \\
6 \\
\end{array}$ & 2 & - & Typology & - & - & - & Aubry 2009 \\
\hline Buraca Grande & Cave & Portugal & $\begin{array}{r}-8.5 \\
5\end{array}$ & $\begin{array}{r}39.9 \\
8\end{array}$ & $8 c / 9 a$ & - & Typology & - & - & - & Aubry et al. 1997 \\
\hline $\begin{array}{l}\text { Fourneau du } \\
\text { Diable }\end{array}$ & Cave & France & 0.59 & $\begin{array}{r}45.3 \\
3\end{array}$ & - & - & Typology & - & - & - & $\begin{array}{l}\text { Plisson and Geneste } \\
1984\end{array}$ \\
\hline le Placard & Cave & France & 0.42 & $\begin{array}{r}45.6 \\
9\end{array}$ & - & - & Typology & - & - & - & $\begin{array}{l}\text { Plisson and Geneste } \\
1984\end{array}$ \\
\hline
\end{tabular}

${ }^{a}$ Calibrated ages and boundaries are calculated by using OxCal 4.2.4 (Bronk Ramsey 2013) and IntCal13 (Reimer et al., 2013). 
The least-cost path analysis reveals a vast network of raw material sources for the lithic materials recovered from different Upper Solutrean occupations (Figure 2), with a major northeast-southwest network corresponding to the Cher Valley Lower Turonian and Claise Valley Upper Turonian flint outcrops. Direct archaeological evidence of the exploitation of translucent, very-fine-grained flint from the lower Cher Valley during Early and Recent Aurignacian, final Gravettian, and Early and Upper Magdalenian have only been known since the beginning of the twenty-first century at site 30 of Mareuil-sur-Cher (Kildea 2008). Similarly, the transport of Upper Turonian flint from the Creuse and Claise Valley is attested through this entire sequence (T. Aubry in Kildea 2008). However, the Lower Turonian translucent variety, which contains black dendrite or point inclusions, is systematically present in Solutrean and Middle Magdalenian assemblages (Aubry 1991, 2009) but is not present in the local flint outcrops, the site 30 Solutrean archaeostratigraphic sequence, or the entire Cher Valley.

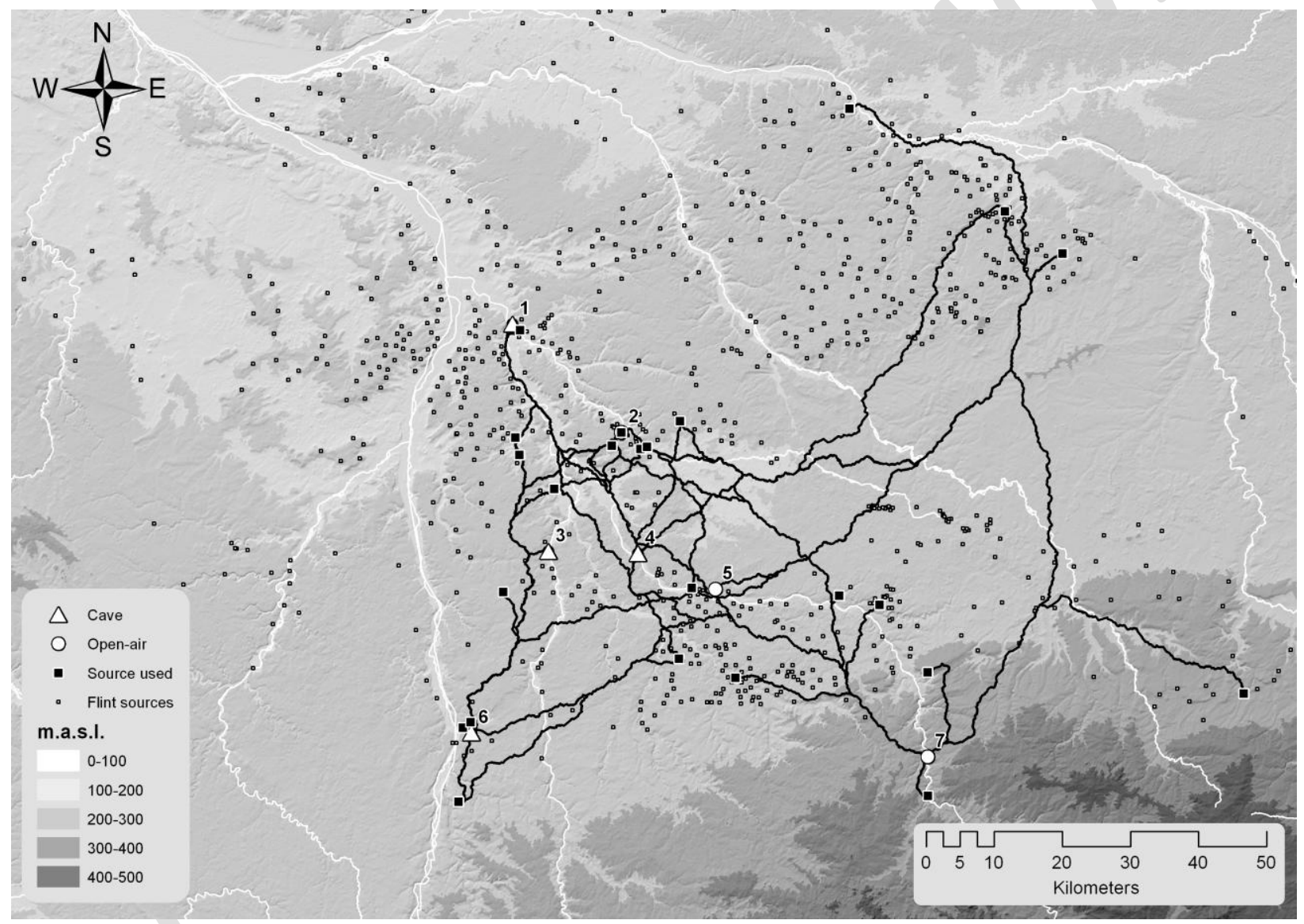

Figure 2. Raw material network in the Creuse Valley during the Upper Solutrean, defined by least-cost paths between sources and discard sites.

\section{1. les Roches d'Abilly; 2. les Maîtreaux; 3. la Guittière; 4. Abri Fritsch; 5. les Riaux; 6. la Tannerie; 7. Fressignes}

Comparison of the network defined by Upper Solutrean assemblages with those defined by sites and occupations from other phases of the Middle and Upper Paleolithic reveals the transport of the same high-quality flint sources across distances that could reach $70 \mathrm{~km}$, both by Neandertals and by anatomically modern humans, from the Middle Paleolithic to the Middle Magdalenian (Figure 3). 


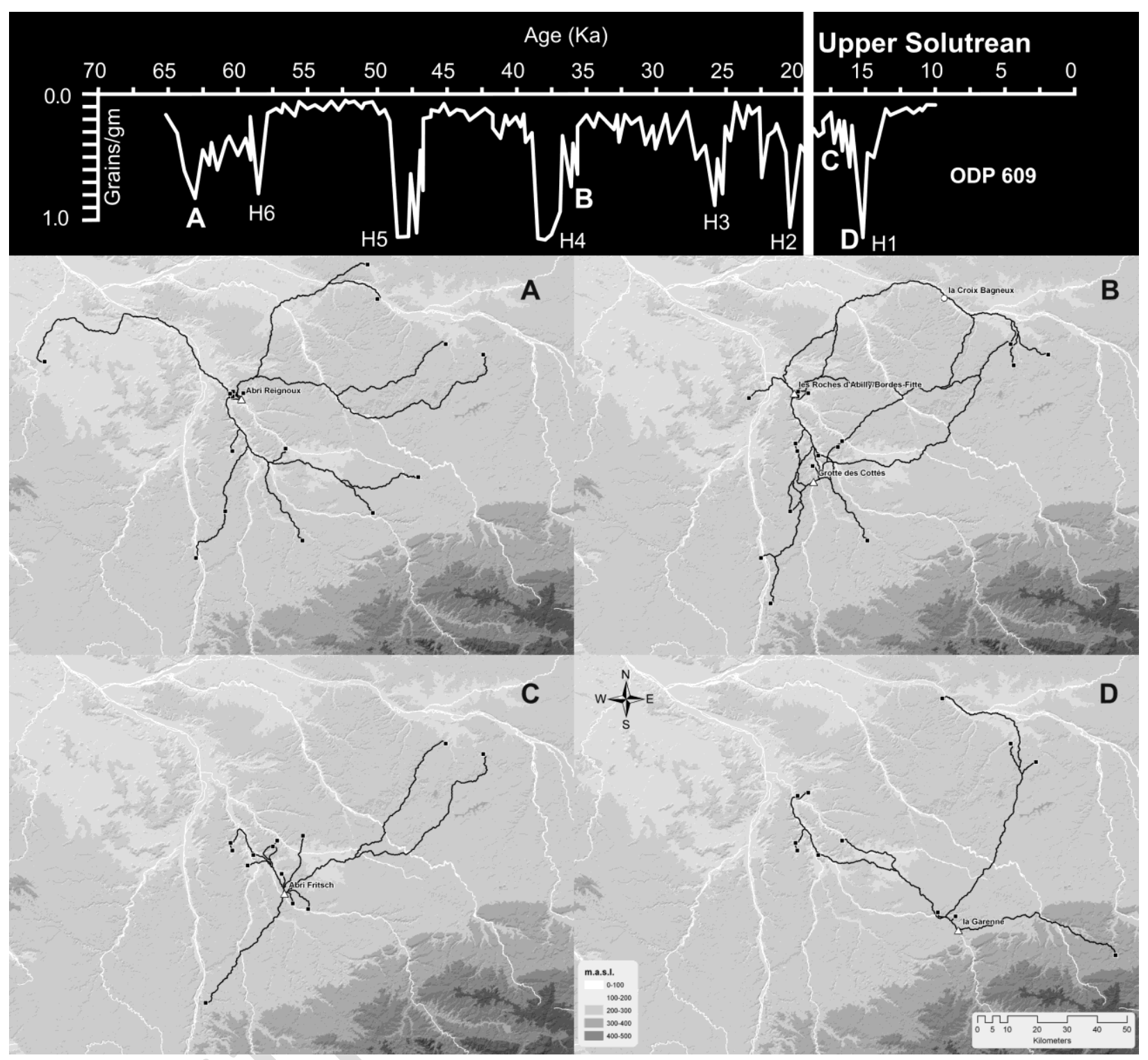

Figure 3. Raw material networks in the Creuse Valley during the Quina Middle Paleolithic phase (A), Aurignacian (les Cottés raw material data from Primault 2003) (B), Badegoulian (C), and Middle Magdalenian (D). Deep sea core ODP 609 used as a proxy of climatic phase.

However, as mentioned for the black inclusion variety of the Lower Turonian, the study reveals small variations in the sources of high-quality flint exploited in each region during different periods. The similarity of these geographic microfacies of high-quality flint systematically used and transported during each cultural phase of the Middle and Upper Paleolithic suggests an existence of specific, localized outcrops recurrently exploited for raw material reserves, blanks, or tools during the different periods. Their existence is demonstrated by workshop sites in the Middle Paleolithic (le Don in the Brenne region; Aubry and Rigaud 2004 and different phases of the Upper Paleolithic (site 30, Mareuil-sur-Cher, Kildea 2008) and the Solutrean and Badegoulian period at Maîtreaux (Aubry et al. 2007a).

The open-air site of Maîtreaux, closely associated with Upper Turonian large flint slabs and nodules, permits a better understanding of flint exploitation and diffusion modalities (Almeida 2005; Almeida et al. 2013; Aubry et al. 1998, 2007b) and confirms that intentional 
heating was used to produce red hematite from the local ferruginous materials (Salomon et al. 2015). The local flint reduction sequences at Maîtreaux were aimed at the production of blades, shouldered points, bladelets, backed bladelets, and small and large laurel leaves (Almeida 2005; Aubry et al. 1998). However, the refitting and study of the bifacial thinning flakes reveal that the large laurel leaves were not finished on-site. Upper Turonian flint preforms, broken during the finishing phase, which are absent at Maîtreaux, were found in Bordes-Fitte rockshelter layer F, and complete preforms were found at la Guittière (Aubry et al. 2009). Large flakes corresponding to the thinning process were recovered in Abri Fritsch's level 10 (Aubry 1991). On the other hand, the Maîtreaux assemblage yields thinning flakes of large laurel leaves made of a nonlocal flint present in the entire Upper Solutrean series (Aubry et al. 2009); in addition, several unretouched blades, or blades that were transformed into endscrapers, which document the first phase of the core preparation in the reduction sequence of shouldered point blank production, were made of flint from three other sources that were also systematically exploited. The exotic pieces (5 of more than 60,000 spatially documented artifacts) reveal the integration of this site in a wide network composed of different high-quality flint sources (Aubry 2013; Mangado et al. 2013) and define this site not only as the departure point of one type of raw material, but as a real network node.

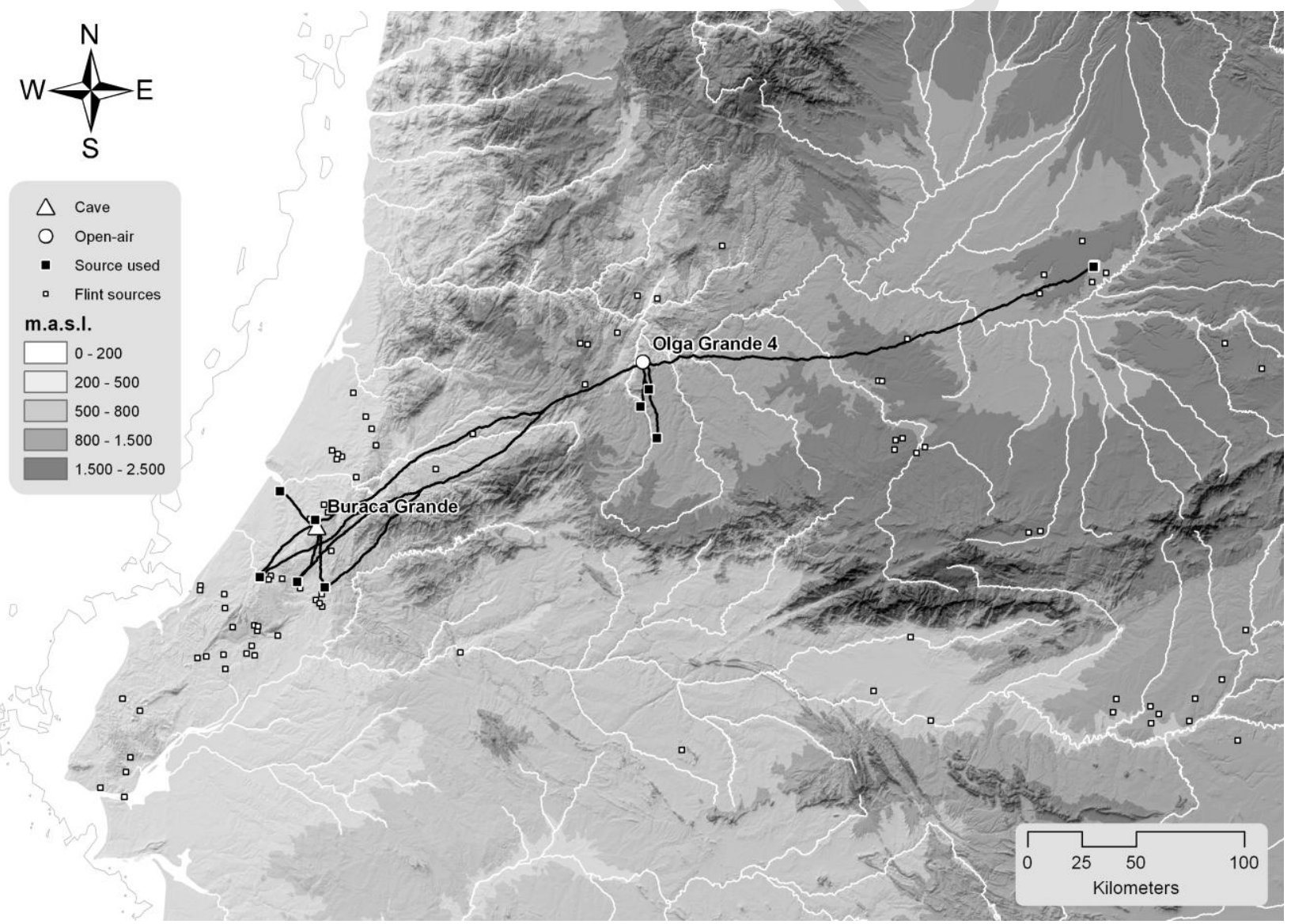

Figure 4. Raw material network in the Côa Valley and the Portuguese Estremadura during the Upper Solutrean, defined by least-cost paths between sources and places of discard.

\section{SOUTHERN TERRITORIES}

The Portuguese sites correspond to two distinct areas. The first is in a south-north valley along the main tectonic fractures of the ancient massif and is composed of crystalline rocks- 
particularly schist and granites. In the lower Côa Valley, best known for its large concentration of open-air Upper Paleolithic rock art (Zilhão, ed. 1997), human settlement from the Gravettian to the Azilian has been shown to be contemporary with the rock art (Aubry, ed. 2009; Zilhão, ed. 1997). More than $150 \mathrm{~km}$ from the nearest flint sources, these sites reveal the use of local and regional fine-grained filonian quartz and also different types of Miocene lacustrine flints from the northern Spanish Meseta and from both Middle and Upper Jurassic and Cretaceous marine environments, as far as $250 \mathrm{~km}$ to the southwest (Aubry, Luís et al. 2012).

The flint used for the production of type B shouldered points found at Olga Grande 4 and 14 indicates a vast network including both distant areas $(150-250 \mathrm{~km})$ as well as closer sources of filonian silicifications $(\sim 50 \mathrm{~km})$ (Figure 4$)$. The local rock crystal, quartz, and quartzite varieties were not used to produce Solutrean points. Despite the distance of the flint sources used for the shouldered point and backed bladelets, these sites' assemblages demonstrate the local production of small blades and bladelets, the use of heat-treatment, and retouch of some of the shouldered points (Aubry, ed. 2009).

Differences arise when comparing Upper Solutrean supply areas with those of the recent Gravettian from Cardina 1, and the Azilian occupation of Fariseu's level 4 (Figure 5). A higher degree of use of distant sources is evident during the Gravettian, and during the Azilian there is a closer link to the Miocene flint from the southern Meseta, which is present in the fluvial terraces of the Tagus Valley. Despite continuing reduction in overall quantities, the same $400 \mathrm{~km}$ maximal extension of the supply network is maintained throughout the entire Upper Paleolithic sequence (Aubry, Luís et al. 2012).

The Buraca Grande cave is located in the Sicó Massif, in a valley deeply incised through Middle Jurassic limestone, where low-quality flint nodules are available in primary and secondary depositional contexts. The lithic assemblage of level 9a, typologically attributed to the Solutrean (Aubry and Almeida 2013), shows the use of this local source but also good-quality flint from sources $30-50 \mathrm{~km}$ to the south. The poor-quality local flint was also used for laurel leaves by systematic heat treatment of the material in the cave, sometimes through different phases of manufacture, as observed in all Solutrean occupations of Portugal (Aubry and Almeida 2013). The lithic raw material supply area and specific sources are consistent throughout the Upper Paleolithic occupation (Middle Gravettian, ca 24,000 BP and Upper Magdalenian 11,000-12,000 BP (Aubry, Luís et al. 2012).

\section{RESULTS: ATLANTIC EUROPE NETWORKS DURING THE LGM}

In the southern group, the longest flint transport distances identified in the Buraca Grande Solutrean assemblage $(<50 \mathrm{~km})$ are similar to those of the regional filonian siliceous rocks observed in the Côa Valley (Fig 4). The origin of the Côa Valley's exotic flint and silcrete suggests a vast network between hunter-gatherer bands $(150-250 \mathrm{~km})$ that integrates the Portuguese Estremadura and the northern Meseta. Data not only reveal the existence of different levels of resource supply in terms of distances traveled, but also demonstrate a clear research bias(i.e., scarcity of Upper Paleolithic fieldwork in the Iberian interior), concerning in the human occupation of the northern Meseta. Miocene lacustrine flint exploitation is consistent in this region throughout the Upper Paleolithic, reaching to the eastern limit of the Plateau in the Côa Valley, but so far no site is securely attested. Direct procurement by the Côa Valley inhabitants from sources in the northern Meseta seems implausible, since the distances in question are only known ethnographically for subarctic societies using watercrafts and dog sleds as means of transportation (Aubry, Luís et al. 2012). 


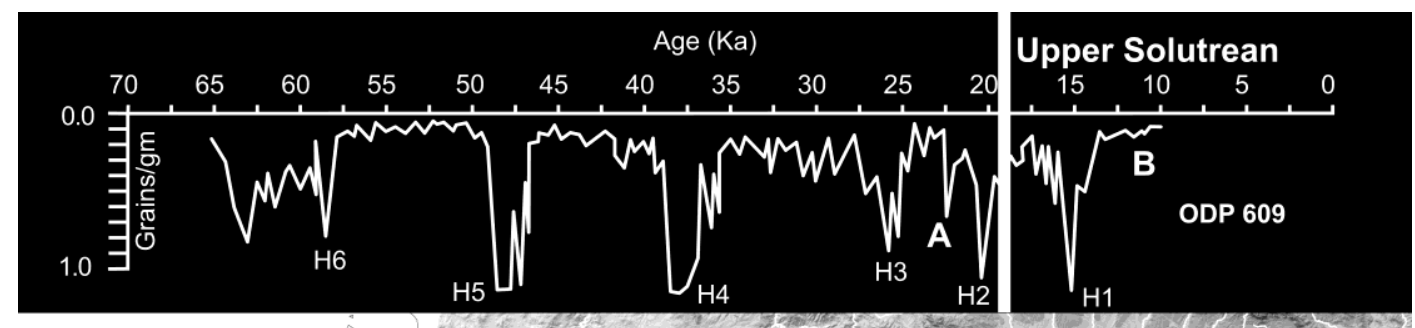

A
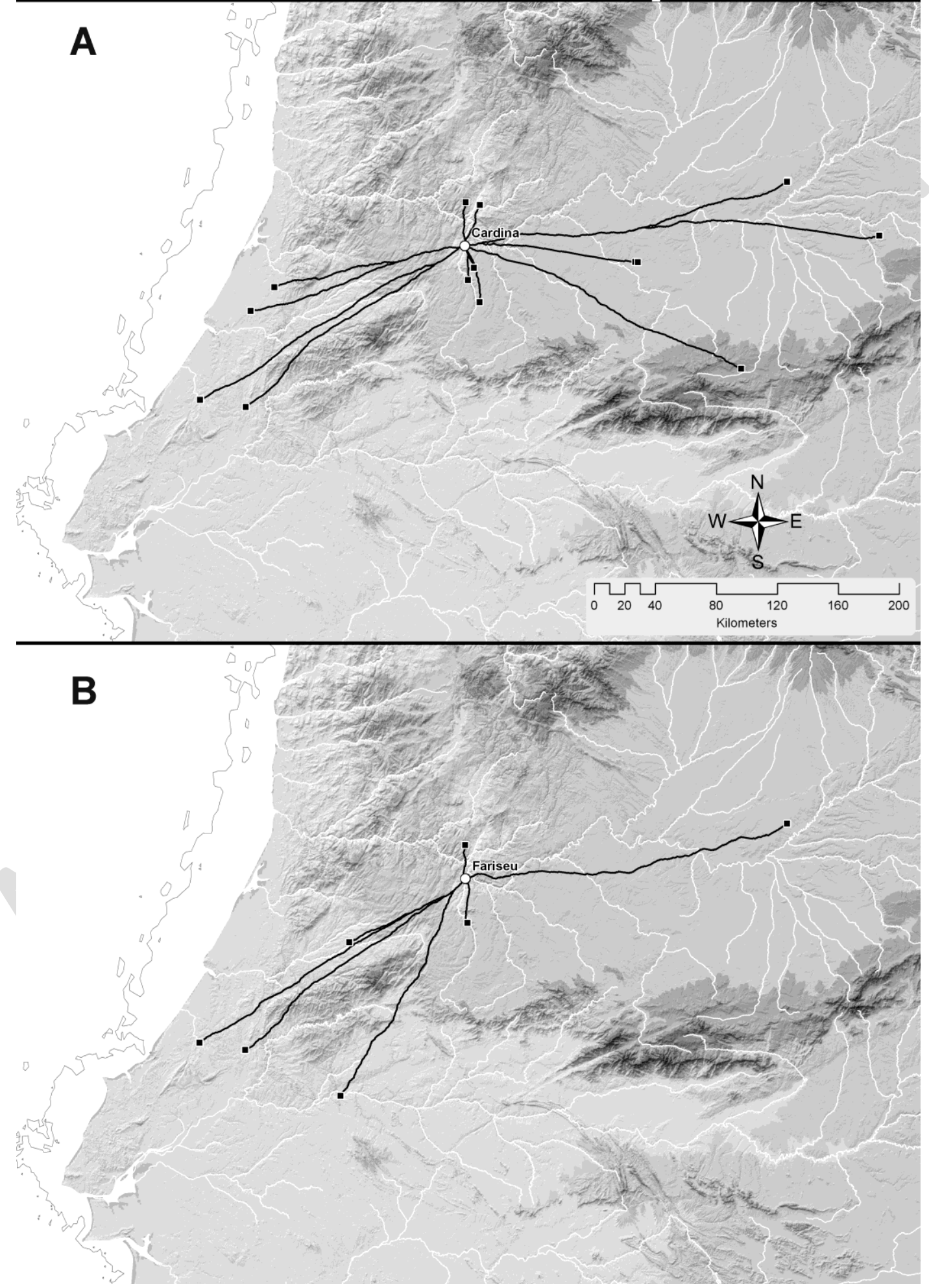

Figure 5. Raw material networks in the Côa Valley during the Recent Gravettian (A) and Azilian (B). 
For the northern group, the Lower Turonian flint of the Cher Valley is systematically present in the Solutrean sites of the Creuse Valley $(60 / 90 \mathrm{~km})$ but also, at a distance of more than $200 \mathrm{~km}$, in some sites of the Charente, Dordogne (Aubry 2013), and in the Lot (Renard 2012). This indicates that Solutrean occupation of the Cher Valley, and other regions of the southern Parisian Basin, are still to be discovered. This is also suggested by the source of the Volgu laurel leaves flint in the Loire Valley, near Gien (Aubry et al. 2004), and recently demonstrated by the discovery of a Solutrean occupation at Ormesson, $70 \mathrm{~km}$ south of Paris (Bodu, Dumarcay and Naton 2014).

Between the two extreme areas studied we have defined least-cost paths between sites and sources in Aquitaine, based on direct knowledge of assemblages, as well as Cantabria, Asturias, and the Pyrenees, based on bibliographical data (Foucher 2007; Tarriño et al. 2013) (Figure 6). The networks demonstrate spatial relations that extend from the southern border of the Parisian Basin to southwestern Iberia, over a wide variety of ecosystems.

One could argue that these networks were never in use at the same time. However, the statistically contemporary dates from sites from different regional groups (Table 1), confirmed by the ages obtained in the Creuse Valley (Abri Fristch, layer 8d; Abri Bordes-Fittes) and the Côa sites (Fariseu, layer 9), argues otherwise, attesting contemporary occupations yielding similar shouldered type B points, even though they present stylistic variation adapted to different regional lithic resources.

Nevertheless, the spatial relations show an occupational void between the northern and southern slopes of the Cantabrian Mountains. This can be explained by an adaptation to ecological pressures, the existence of reserve areas (Straus 2013), or by the researchers' lack of knowledge of raw material sources and their study biases (Aubry 2013). Only recently has it been demonstrated that Miocene lacustrine sources from the Douro depression of the northern Meseta were used in the Côa Valley, more than $150 \mathrm{~km}$ away. On the other hand, one of the least-cost paths between the Treviño flint and the Asturian site of Las Caldas (Tarriño et al. 2013) passes a mere $27 \mathrm{~km}$ from the Mucientes Miocene flint sources used in the Côa Valley. It is therefore necessary to determine whether or not lacustrine flint from the Valladolid area is present in the Cantabrian and Asturian assemblages.

\section{DISCUSSION: LITHIC RESOURCE SUPPLY AS A PROXY FOR THE FORAGERS' SOCIAL ORGANIZATION}

Our study relies on lithic raw material source areas to define spatial networks, based on both cave and open-air site lithic assemblages. These spatial relationships ignore important evidence that can also be used in such studies-most importantly, faunal analysis. Data on large herbivores provide a different perspective but are also affected by various biases (taphonomy, human prey selection, accumulations from natural processes or other predators, etc.). The main objection to the use of faunal remains recovered in archaeological sites for paleoenvironment reconstruction is the absence of valuable data on the ecology of extinct species (e.g., Bos primeginius) and the ecological significance of present-day distribution-namely the modern range of Capra pyrenaica and Rupicapra rupicapra, which were present at low elevations in Iberia during the last glacial phase. Moreover, ungulates exhibit substantial ecological plasticity (Guthrie 1982) and time lags in their responses to climatic shifts (Montuire and Girard 1998). For these reasons, the viability of using modern distributions of animal species to infer past ecology has been questioned (Rivals et al. 2009). 


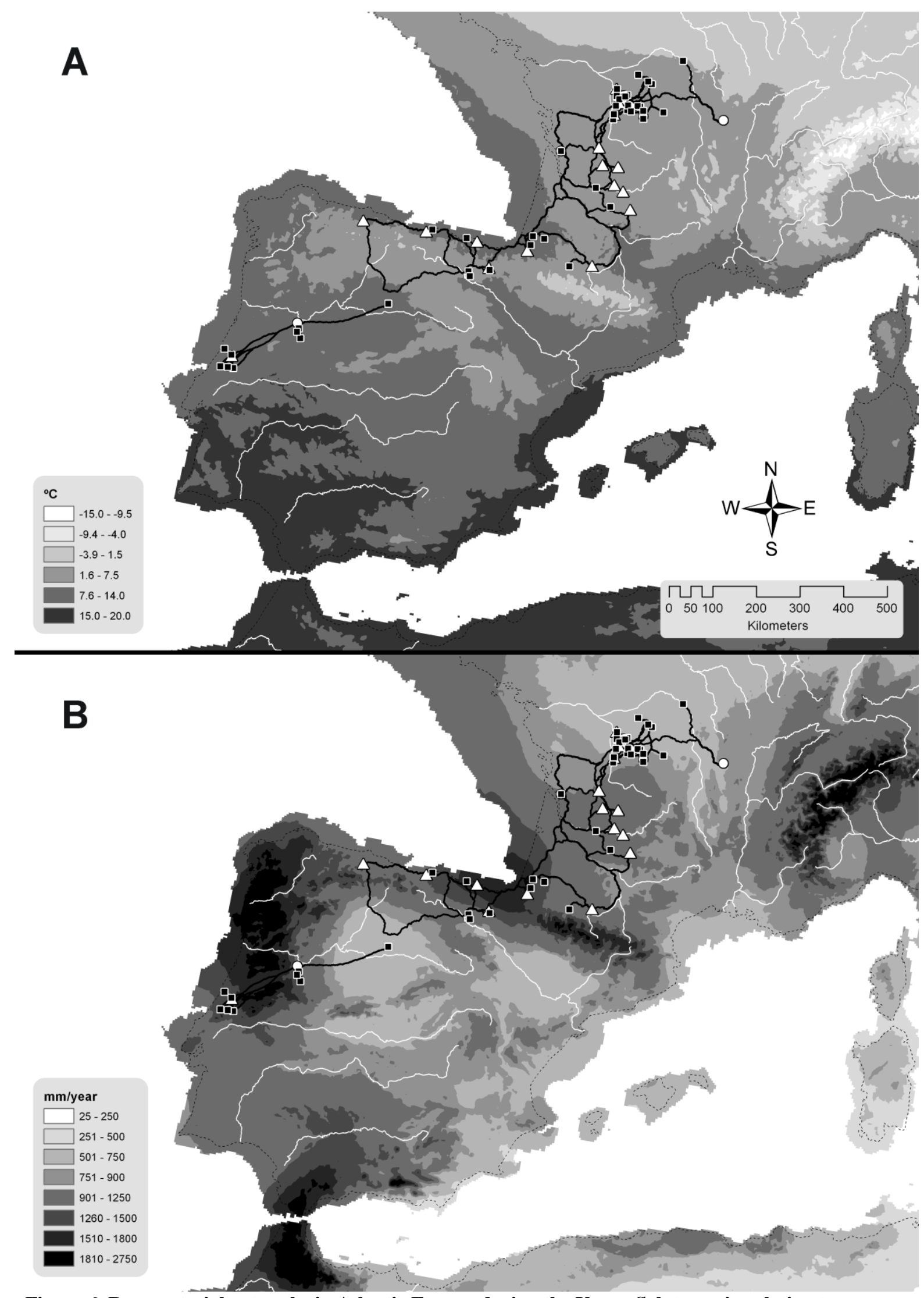

Figure 6. Raw material networks in Atlantic Europe during the Upper Solutrean in relation to average temperature (A) and annual precipitation (B) data from CCSM LGM climatic model (retrieved from http://www.worldclim.org/past [Accessed 26 Jan 2015]). 
In order to test how raw material supply may be related to climatic, environmental, and resource variation we have presented a comparison of raw material network with paleoclimatic reconstructions based on dated Middle and Upper Paleolithic occupations (Figures 3 and 5). The data do not reveal a clear chronological pattern, differences between Middle and Upper Paleolithic raw material networks, or any clear relationship between the cold conditions and the extension of human geographical range and sources of flint. Available data concerning faunal remains indicate that the use of the lower Turonian flint from the Cher Valley is attested to in the occupation levels where reindeer are dominant (Despriée et al. 2009; Trotignon et al. 1984), but also in occupations dominated by large bovines and equids, where reindeers are absent or marginally represented, in the Middle Paleolithic assemblages of the Roches d'Abilly site (Aubry et al. 2013), despite both sites having the same Creuse Valley open environment.

The faunal record for the Upper Paleolithic sequence preserved in caves and rockshelters of central Portugal is clearly distinct, reflecting a different impact of the cold millennial-scale climate oscillations established from the marine record of the western Iberian coast. The ratio of rabbits to ungulates at these sites increases from the Mousterian to the Magdalenian (Aubry et al. 2001; Davis 2002; Haws 2011; Hockett and Haws 2009; Zilhão 1997b), which is interpreted as the result of a gradual increase in hunting pressure on the environment, probably because of higher human population density (Davis 2002). Red deer and wild boar dominate during the Late Glacial, in contrast to a better representation of equids, ibex, chamois, and aurochs before and during the LGM (Aubry et al. 2001; Davis 2002; Haws 2011; Zilhão 1997). The Sicó Massif record in west-central Portugal reveals that flint sources from southern outcrops were systematically used from the Gravettian to the Final Magdalenian (Aubry et al. 2012b), despite the changes in observed faunal assemblages during the same period. Gruta da Oliveira (Torres Novas), a cave in the Almonda River karstic system between the Serra d'Aire Massif and the Cenozoic depression of the Tagus Valley (Zilhão et al. 2013), preserves a sequence of Middle Paleolithic occupation (90-40 kya). The study of the raw material sources of the Middle Paleolithic level 14 assemblage, dated to $45 \mathrm{kya}$, has revealed the use of local quartzite, associated with Upper and Middle Jurassic and Cretaceous flint transported 0-20 km from the source (Matias 2012), which is similar to the sources of the Final Magdalenian raw material at Coelhos Cave in the same karstic system (Gameiro et al. 2013).

The fact that in both northern and southern groups raw material sources are not directly related to environmental change and the biotic resources exploited may account for the relative stability of the networks they define. Basic geology did not change through time, but knowledge and use of geology may have changed. Cultural choices exist, and they are noteworthy when networks dating to different times are being compared. Nevertheless, these cultural choices will always have to incorporate raw material constraints, and they will also reflect the organization of transport by the hunter-gatherers: whether it is embedded within daily subsistence forays (Binford 1980), the result of long-distance procurement (Féblot-Augustins and Perlès 1992), or exchange (Gamble 1999).

Whatever the case, these spatial relations can be used as a proxy for the organization of the societies that established these networks. We propose to interpret the different geographic scales identified in raw material supply independently of the region studied in response to the different levels of social organization of hunter-gatherer groups as proposed by Wobst (1974). Through the application of a central place model (Whallon 2006; Wobst 1974), the smallest spatial level of the local band would correspond to the local source ranges documented by flint transport reflected in Buraca Grande assemblages, which is similar to those defined by the regional siliceous filonian varieties of the Côa Valley sites. Miocene and exotic marine flint at these latter sites can be equated with maximal or connubium bands (Wobst 1974), the safety network upon which bands depend (Whallon 2006) and within which ties have to be maintained. 
In this scenario, the presence of rock art at the western limit of the Meseta, the center of a network that connects the northern Meseta with the Atlantic Southwest, is suggestive of an interpretation of the Côa Valley as an aggregation area (Aubry, Luís et al. 2012). The fact that exotic raw materials are constantly present in significant quantities, reflecting consistent needs, and the evident knowledge of scarce local siliceous sources argue against the interpretation that the materials were transported in the context of casual travel. The same kind of inference could be applied to regional transport of Lower and Upper Turonian flint in northern Charente (le Placard), Dordogne (le Fourneau du Diable) and Lot (le Cuzoul de Vers), Upper Solutrean occupations, which corresponds to the distribution cluster of type A shouldered points (Aubry 2013).

In summary, the data suggest that raw material sources define two networks at different scales throughout Atlantic Europe, independently of local environmental variation, and a continuous network between different Solutrean site concentrations is coming into focus. Besides establishing relations between different site concentrations, the territories defined by lithic resource exploitation reveal the systematic use of lithic resources from areas where Solutrean sites are not known. In our view, this fact indicates that the present Solutrean record is still incomplete since it is mainly based on easily detected and long excavated cave and rockshelter sites, and that most of the open-air sites related to flint exploitation and logistic hunting are yet to be discovered.

NOTE

We would like to thank John C. Willman for his review of the text and constructive comments. The text was lightly edited by L. G. Straus, who invited us to participate in the UISPP symposium on human adaptations to the Last Glacial Maximum in western Europe.

\section{REFERENCES CITED}

Allain, Jacques. 1989. "La fin du Paléolithique supérieur en région centre," in Le Magdalenien en Europe: La structuration du Magdalenien: Actes du Colloque de Mayence 1987. Edited by Marcel Otte, pp. 193-214. Liège: Université de Liège (ERAUL 38).

Almeida, Miguel. 2005. Première approche à l'interprétation palethnologique du groupe solutréen des Maîtreaux, perspectives sur la technologie et répartition spatiale des vestiges lithiques et ses implications pour l'interprétation du registre archéologique. MA dissertation, University of Paris.

Almeida, M., T. Aubry, M. J. Neves, and B. Walter. 2013. "Les Maîtreaux: Caractères technoéconomiques et palethnologiques d'une halte de production lithique solutréen," in Le Solutréen 40 ans après Smith'66, pp. 119-26. 47e Supplément à la Revue Archéologique du Centre de la France. Chambray-Les-Tours: ARCHEA, FERACF.

Angelucci, Diego E. 2002. "The Lagar Velho rockshelter (Lapedo, Leiria, Portugal): Stratigraphic record and palaeoenvironment during the Oxygen Isotope stage 2," in $1^{o}$ Congresso Nacional de Geomorfologia, pp. 35-48. Lisboa: Publicações da Associação Portuguesa de Geomorfólogos.

Aubry, Thierry. 1991. L'exploitation des ressources en matières premières lithiques dans les gisements solutréens et badegouliens du bassin versant de la Creuse (France). $\mathrm{PhD}$ dissertation, University de Bordeaux.

. 2005. "Etude de l'approvisionnement en matières premières lithiques d'ensembles archéologiques, remarques méthodologiques et terminologiques," in Comportements des hommes du paléolithique moyen et supérieur en Europe: Territoire et milieux. Edited by D. Vialou, J. Renault-Miskosvky, and M. Patou-Mathis, pp. 87-99. Liège: Université de Liège (ERAUL 111). 
. 2009. “L'approvisionnement en matières premières lithiques sur le site de «La Garenne» (Saint-Marcel, Indre)," in Archéologie du Val de Creuse en Berry. Edited by J. Despriée, S. Tymula, and A. Rigaud, pp. 37-46. Bulletin de l'Association pour la Sauvegarde du Site Archéologique d'Argentomagus et Amis du Musée, numéro spécial 2. Argenton-surCreuse.

. 2013. "Approches spatiales du Solutréen: Le dessous des cartes et des plans," in Le Solutréen 40 ans après Smith'66, pp. 197-212. Supplément à la Revue Archéologique du Centre de la France 47. Chambray-Les-Tours: ARCHEA, FERACF.

Aubry, Thierry., ed. 2009. 200 séculos da história do Vale do Côa: Incursões na vida quotidiana do caçadores-artistas do Paleolítico. Trabalhos de Arqueologia 52. Lisboa: Igespar IP.

Aubry, Thierry, and Miguel Almeida. 2013. "Analyse critique des bases chronostratigraphiques de la structuration du Solutréen," in Le Solutréen 40 ans après Smith'66, pp. 37-52. Supplément à la Revue Archéologique du Centre de la France 47. Chambray-Les-Tours: ARCHEA, FERACF.

Aubry, Thierry, and André Rigaud. 2004. "Les industries Levallois sur éclats en Brenne," in Préhistoire du Val de Creuse en Berry.

'Argentomagus.

Aubry, T., M. Almeida, P. Candela, F.X. Chauvière, L. Dimuccio, L. Fontana, M. Liard, J. C. Marquet, M-J. Neves, J. B. Peyrouse, and B. Walter. 2013. "Le Paléolithique supérieur ancien dans le sud-ouest du Bassin parisien: Du Châtelperronien au Gravettien dans les vallées de la Creuse et de la Claise," in Le Paléolithique supérieur ancien de l'Europe du Nord-ouest: Réflexions et synthèses à partir d'un projet collectif de recherche sur le centre et le sud du Bassin parisien. Edited by P. Bodu, L. Chehmana, L. Klaric, L. Mevel, S. Soriano, and N. Teyssandier, pp. 299-316. Paris: Société Préhistorique Française (Mémoire 56).

Aubry, T., M. Almeida, L. Chehmana, H. Thiennet, and B. Walter. 2007a. De la fin du Solutréen au Magdalénien moyen dans les vallées de la Claise et de la Creuse. Bulletin de la Société Préhistorique Française 104 (4):699-714. http://dx.doi.org/10.3406/bspf.2007.13617

Aubry, T., M. Almeida, J. Mangado Llach, M. J. Neves, J. B. Peyrouse, and B. Walter 2007b. "Mythes et réalités préhistoriques: Apport du site des Maîtreaux à la définition de la variabilité des productions lithiques au Solutréen," in

Française, vol. 3. Edited by J. Evin, pp. 105-24. Paris.

Aubry, T., M. Almeida, J. Mangado Llach, J. Pelegrin, J. B. Peyrouse, M. J. Neves, and B. Walter. 2009. "Les grandes feuilles de laurier solutréennes: Données intrinsèques et contexte de découverte," in

M. Lauwers, and B. Quilliec, pp. 87-99. Antibes: Editions APDCA.

Aubry, T., M. Bradley, M. Almeida, B. Walter, M. J. Neves, J. Pelegrin, M. Lenoir, and M. Tiffagom. 2008. Solutrean laurel leaf production at Maitreaux: An experimental approach guided by techno-economic analysis. World Archaeology 40(1):48-66. http://dx.doi.org/10.1080/00438240701843538

Aubry, T., J. P. Brugal, F. X. Chauvière, I. Figueiral, M. H Moura, and H. Plisson. 2001. Modalités d'occupation au Paléolithique supérieur dans la grotte de Buraca Escura (Redinha, Pombal, Portugal). Revista Portuguesa de Arqueologia 4(2):19-46.

Aubry, T., L. A. Dimuccio, M. Almeida, J. P. Buylaert, L. Fontana, T. Higham, M. Liard, A. Murray, M. J. Neves, J. B. Peyrouse, and B. Walter. 2012. Stratigraphic and technological evidences from the Middle Palaeolithic-Châtelperronian-Aurignacian 
record at the Bordes-Fitte rockshelter (Roches d'Abilly site, Central France). Journal of Human Evolution 62 (1):116-37. http://dx.doi.org/10.1016/j.jhevol.2011.10.009

Aubry, Thierry, L. A. Dimuccio, M. Almeida, M. J. Neves, D. E. Angelucci, and L. Cunha. 2011. Palaeoenvironmental forcing during the Middle-Upper Palaeolithic transition in central-western Portugal. Quaternary Research 75(1):66-79. http://dx.doi.org/10.1016/j.yqres.2010.11.002

Aubry, Thierry, M. Fontugne, and M. H. Moura. 1997. Les occupations de La Grotte de Buraca Grande depuis le Paléolithique supérieur et les apports de la séquence Holocène à l'étude de la transition Mésolithique/Néolithique au Portugal. Bulletin de la Société Préhistorique Française 94(2):182-90. http://dx.doi.org/10.3406/bspf.1997.10876

Aubry, T., L. Luís, J. Mangado Llach, and H. Matias. 2012. We will be known by the tracks we leave behind: Exotic lithic raw materials, mobility and social networking among the Côa Valley foragers (Portugal). Journal of Anthropological Archaeology 31(4):528-50. http://dx.doi.org/10.1016/j.jaa.2012.05.003

Aubry, T., J. Mangado Llach, and H. Matias. 2014. "Matérias-primas das ferramentas em pedra lascada da pré-história do centro e nordeste de Portugal," in Proveniências de materiais geológicos. Edited by P. A. Dinis, A. Gomes, and S. Monteiro-Rodrigues, pp. 165-92. Porto: Associação Portuguesa para o Estudo do Quaternário.

Aubry, T., M. J. Neves, M. Almeida, and J. Mangado Llach. 2008. "Modalidades de aprovisionamento em matérias-primas líticas no baixo Mondego durante o Holocénico: Dados novos e revisão de séries arqueológicas," in Actas del IV Congreso Neolitico Peninsular: 27-30 de noviembre de 2006, vol. 2. Edited by M. , J. de Alicante.

$$
\text { , and } \mathrm{J} \text {. }
$$

, pp. 258-65. Alicante: MARQ, Diputacion Provincial

Aubry, T., J. B. Peyrouse, and B. Walter. 2004. Les feuilles de laurier de Volgu (Saône et Loire): Une énigme en partie résolue? Paléo 15:245-50.

Aubry, Thierry, B. Walter, M. Almeida, and M. J. Neves. 2003. "Solutrean laurel leaf point production and raw material procurement during the Last Glacial Maximum in southern Europe: Two examples from central France and Portugal," in Multiple approaches to biface variability. Edited by Marie Soressi and Harold Lewis Dibble, pp. 165-82. Philadelphia: Museum of Archaeology and Anthropology.

Aubry, T., B. Walter, E. Robin, H. Plisson, and M. Benhabdelhadi. 1998. Le site solutréen des Maitreaux (Bossay-sur-Claise, Indre-et-Loire): Un faciès original de production lithique. Paléo 10:163-85. http://dx.doi.org/10.3406/pal.1998.1135

Becker, J. J., D. T. Sandwell, W. H. F. Smith, J. Braud, B. Binder, J. Depner, D. Fabre, J. Factor, S. Ingalls, S-H. Kim, R. Ladner, K. Marks, S. Nelson, A. Pharaoh, R. Trimmer, J. von Rosenberg, G. Wallace, and P. Weatherall. 2009. Global bathymetry and elevation data at 30 arc seconds resolution: SRTM30_PLUS. Marine Geodesy 32(4):355-71. http://dx.doi.org/10.1080/01490410903297766

Binford, L. R. 1980. Willow smoke and dogs' tails: Hunter-gatherer settlement systems and archaeological site formation. American Antiquity 45:4-20. http://dx.doi.org/10.2307/279653

- 2001. Constructing frames of reference: An analytical method for archaeological theory building using hunter-gatherer and environmental data sets. Berkeley: University of California Press.

Bodu, P., G. Dumarcay, and H. G. Naton. 2014. Un nouveau gisement solutréen en Île-deFrance, le site des Bossats à Ormesson (Seine-et-Marne). Bulletin de la Société Préhistorique Française 111(2):225-54. 
Bronk Ramsey, C., 2013. OxCal 4.2. Available at: http://c14.arch.ox.ac.uk/oxcal. [Accessed 25 Aug 2015].

Davis, S. J. M. 2002. The mammals and birds from the Gruta do Caldeirão, Portugal. Revista Portuguesa de Arqueologia 5(2):29-98.

Demars, P. Y. 1982. L’utilisation du silex au Paléolithique supérieur: Choix, approvisionnement, circulation: L'exemple du Bassin de Brive. Cahiers du Quaternaire 5. Paris: CNRS.

Despriée, J., S. Tymula, and A. Rigaud, eds. 2009. Archéologie du Val de Creuse en Berry: Le Coteau de la Garenne, PCR Etudes 1999-2001. Bulletin de 1'Association pour la Sauvegarde du Site Archéologique d'Argentomagus et Amis du Musée, numéro spécial 2. Argenton-sur-Creuse:

Easley, D., and J. Kleinberg. 2010. Networks, crowds, and markets: Reasoning about a highly connected world. Cambridge: Cambridge University Press.

Elith, J., and J. R. Leathwick. 2009. Species distribution models: Ecological explanation and prediction across space and time. Annual Review of Ecology, Evolution, and Systematics 40:677-97. http://dx.doi.org/10.1146/annurev.ecolsys.110308.120159

Féblot-Augustins, Jehanne. 1997. La circulation des matières-premières au Paléolithique. Liège: Université de Liège (ERAUL 75).

Féblot-Augustins, J., and C. Perles. 1992. "Perspectives ethnoarchéologiques sur l'échange a longue distance," in Ethnoarchéologie: Justification, problèmes, limites, pp. 195-209. $\mathrm{XII}^{\mathrm{e}}$ Rencontres Internationales d'Archeologie et d'Histoire d'Antibes. Juan-les-Pins: APDCA.

Fernandes, P., J. P. Raynal, and M. H. Moncel. 2008. Middle Palaeolithic raw material gathering, territories and human mobility in the southern Massif Central, France: First results from a petro-archaeological study on flint. Journal of Archaeological Science 35:2367-70. http://dx.doi.org/10.1016/j.jas.2008.02.012

Foucher, Pascal. 2007. "Les territoires solutréens des Pyrénées-Cantabres, d'après les armatures foliacées et la circulation des matières premières," in Les territoires solutréens des Pyrénées-Cantabres, d'après les armatures foliacées et la circulation des matières premières, 2004, Tarascon, France, pp. 279-99. Available at https://hal.archivesouvertes.fr/hal-00834408.

Gamble, Clive. 1999. The Palaeolithic societies of Europe. Cambridge: Cambridge University Press.

Gameiro, C., T. Aubry, and F. Almeida. 2013. "A variabilidade regional das indústrias líticas do final do Paleolítico superior em Portugal," in Arqueologia em Portugal-150 anos, pp. 277-87. Lisboa: Associação Portuguesa dos Arqueológos Portugueses.

Guthrie, R. D. 1982. "Mammals of the mammoth steppe as paleoenvironmental indicators," in Paleoecology of Beringia. Edited by D. M. Hopkins, J. V. Matthews, C. E. Schweger, and S. B. Young, pp. 307-26. New York: Academic Press.

Haws, Jonathan A. 2011. Paleolithic socionatural relationships during MIS 3 and 2 in central Portugal. Quaternary International 264:61-77. http://dx.doi.org/10.1016/j.quaint.2011.10.003

Hockett, Bryan, and Jonathan Haws. 2009. Continuity in animal resource diversity in the Late Pleistocene human diet of central Portugal. Before Farming 2009 (2) (January 1): 1-14. http://dx.doi.org/10.3828/bfarm.2009.2.2

Jarvis, A., H. I. Reuter, A. Nelson, and E. Guevara. 2008. Hole-filled SRTM for the globe, Version 4, available from the CGIAR-CSI SRTM 90m Database. (Available online at http://srtm.csi.cgiar.org) 
Johnsen, S. J., D. Dahl-Jensen, N. Gundestrup, J. P. Steffensen, H. B. Clausen, H. Miller, V. Masson-Delmotte, A. E. Sveinbjörnsdottir, and J. White. 2001. Oxygen isotope and palaeotemperature records from six Greenland ice-core stations: Camp Century, Dye-3, GRIP, GISP2, Renland and NorthGRIP. Journal of Quaternary Science 16(4):299-307. http://dx.doi.org/10.1002/jqs.622

Kelly, R. L. 1995. The foraging spectrum: Diversity in hunter-gatherer lifeways. Washington, DC: Smithsonian Institution Press.

Kildea, F. 2008. La Croix de Bagneux à Mareuil-sur-Cher. Rapport Final d'Opérations. Service Régional d'Achéologie Centre.

Larick, R. Roy. 1984. The circulation of Solutrean foliate point cherts: Residential mobility in the Périgord. PhD dissertation, State University of New York, Binghamton.

Mangado Llach, Xavier. 2002. La caracterización y el aprovisionamiento de los recursos abióticos en la prehistoria de Cataluña: Las materias primas silíceas del Paleolítico superior final y el Epipaleolítico. $\mathrm{PhD}$ dissertation, University of Barcelona.

Mangado Llach, X., T. Aubry, M. Almeida, J. B. Peyrouse, and B. Walter. 2013. "Déplacements et modalités d'exploitation des silex turoniens de la marge méridionale du bassin parisien pendant le Solutréen," in Le Solutréen 40 ans après Smith'66, pp. 233-38. Supplément à la Revue Archéologique du Centre de la France 47. Chambray-Les-Tours: ARCHEA, FERACF.

Matias, Henrique. 2012. O aprovisionamento de matérias-primas líticas na Gruta da Oliveira (Torres Novas). MSc dissertation, University of Lisbon.

Matsumoto, Go. 2008. Availability of least-cost pathway analysis for the study of the Inka road system. Poster presented at the 36th Annual Midwest Conference on Andean and Amazonian Archaeology and Ethnohistory, February 23-24, University of Wisconsin, Madison. (Available at http://www.academia.edu/326547/Availability_of_LeastCost_Pathway_Analysis_for_the_Study_of_Inka_Road_System)

Montuire, Sophie, and Catherine Girard. 1998. Adaptation to environmental changes: Communities need more time than species. Paläontologische Zeitschrift 72(1-2):241-48. http://dx.doi.org/10.1007/BF02987828

Patte, E. 1944. Le Solutréen dans la Vienne. Bulletin de la Société Préhistorique Française 4:42-46. http://dx.doi.org/10.3406/bspf.1944.1877

Pelegrin, J. 2007. À quoi servaient ces pierres taillées exceptionnelles. Archéologia 444:40-41.

Pelegrin J., C. Karlin, and P. Bodu. 1988. "Chaînes opératoires: Un outil pour le préhistorien," in Technologie préhistorique. Edited by J. Tixier, pp. 55-62. Notes et Monographies Techniques du CRA 25.Paris: Edition du CNRS.

Plisson, H., and J. M. Geneste. 1984. Analyse technologique des pointes à cran solutréennes du Placard (Charente), du Fourneau du diable, du Pech de la Boissière et Combe Saunière (Dordogne). Paléo 1:65-106.

Pradel, Dr. 1950. Le Solutréen supérieur de la grotte de La Tannerie, Commune de Lussac-LesChâteaux (Vienne). Bulletin de la Société Préhistorique de France 47 (9):465-71. http://dx.doi.org/10.3406/bspf.1950.2739

Primault, Jérôme. 2003. Exploitation et diffusion des silex de la région du Grand-Pressigny au Paléolithique. PhD dissertation. University of Paris.

Reimer, P.J., Bard, E., Bayliss, A., Beck, J.W., Blackwell, P.G., Bronk Ramsey, C., Buck, C.E., Edwards, R.L., Friedrich, M., Grootes, P.M., Guilderson, T.P., Haflidason, H., Hajdas, I., Hatté, C., Heaton, T.J., Hoffmann, D.L., Hogg, A.G., Hughen, K.A., Kaiser, K.F., Kromer, B., Manning, S.W., Niu, M., Reimer, R.W., Richards, D.A., Scott, E.M., Southon, J.R., Turney, C.S.M., van der Plicht, J., 2013. IntCal13 and Marine13 radiocarbon age calibration curves, 0-50,000 years cal BP. Radiocarbon 55, 1869-1887. 
Renard, C. 2012. "L'organisation des productions lithiques solutréennes du Cuzoul (Vers, Lot): Implications techno-économiques," in Solutréen et Badegoulien au Cuzoul de Vers: Des chasseurs de rennes en Quercy. Edited by J. Clottes, J. P. Giraud, and P. Chalard, pp. 8992. Liège: Université de Liège (ERAUL 131).

Rivals, F., E. Schulz, and T.M. Kaiser. 2009. Late and Middle Pleistocene ungulates' dietary diversity in western Europe indicates variations of Neanderthal paleoenvironments through time and space. Quaternary Science Reviews 28:3388-3400. http://dx.doi.org/10.1016/j.quascirev.2009.09.004

Salomon, H., C. Vignaud, S. Lahlil, and N. Menguy. 2015. Solutrean and Magdalenian ferruginous rocks heat-treatment: Accidental and/or deliberate action? Journal of Archaeological Science 55:100-12. http://dx.doi.org/10.1016/j.jas.2014.12.024

Sanchez Goñi, M. F., and S. P. Harrison. 2010. Millennial-scale climatic variability and vegetation changes during the last glacial: Concepts and terminology. Quaternary Science Reviews 29:2823-27. http://dx.doi.org/10.1016/j.quascirev.2009.11.014

Schmidt, I., M. Bradtmöller, M. Kehl, A. Pastoors, Y. Tafelmaier, B. Weninger, and G. C. Weniger. 2012. Rapid climate change and variability of settlement patterns in Iberia during the Late Pleistocene. Quaternary International 274:179-204. http://dx.doi.org/10.1016/j.quaint.2012.01.018

Seronie-Vivien, M., and M. R. Seronie-Vivien. 1987. Les silex du Mésozö̈que nord-aquitain: Approche géologique de l'étude des silex pour servir à la recherche préhistorique. Supplément du Bulletin de la Société Linnéenne de Bordeaux 25.

Shackleton, N. J., R. G. Fairbanks, T. C. Chiu, and F. Parrenin. 2004. Absolute calibration of the Greenland time scale: Implications for Antarctic time scales and for ${ }^{14} \mathrm{C}$. Quaternary Science Reviews 23:1513-22. http://dx.doi.org/10.1016/j.quascirev.2004.03.006

Smith, P. E. L. 1966. Le Solutréen en France. Mémoire de l'Institut de Préhistoire de l'Université de Bordeaux 5. Bordeaux: Imprimerie Delmas.

Straus, L. G. 2012. El Solutrense: 40 años de reflexiones de un arqueólogo norteamericano. Espacio Tiempo y Forma, serie I, nueva época. Prehistoria y Arqueología 5:27-36. . 2013. Qu'est-ce que “le Solutréen”? in Le Solutréen 40 ans après Smith'66 , pp. 27-36. $47^{\mathrm{e}}$ Supplément à la Revue Archéologique du Centre de la France. Chambray-Les-Tours: ARCHEA, FERACF.

Tarriño, Antonio, Ana Cava, and Ignacio Barandiarán. 2013. "Recursos líticos en las indústrias del Solutrense cantábrico: El caso de Altamira (Cantabria, España),” in Le Solutréen: 40 ans après Smith’ 66, pp. 262-72. Supplément à la Revue Archéologique du Centre de la France 47. Chambray-Les-Tours: ARCHEA/FERACF.

Tobler, Waldo. 1993. Three presentations on geographical analysis and modeling. Technical Report 93-1. National Center for Geographic Information and Analysis. (http://www.ncgia.ucsb.edu/Publications/Tech_Reports/93/93-1.PDF) Accessed 26 January 2015.

Trotignon, F., T. Poulain, and A. Leroi-Gourhan. 1984. Études sur l'Abri Fritsch (Indre). Supplément à Gallia Préhistoire 19.

Valladas, H., N. Mercier, L. Froget, J. L. Joron, J. L. Reyss, and T. Aubry. 2001. TL dating of Upper Palaeolithic sites in the Côa Valley (Portugal). Quaternary Science Reviews 20(59):939-43. http://dx.doi.org/10.1016/S0277-3791(00)00026-3

Vialou, Denis, and Águeda Vilhena Vialou. 2012. "Fressignes (Indre, France): Campement de chasseurs Solutréens aux limites de l'extrême septentrional. Espacio Tiempo y Forma, serie 1. Prehistoria y Arqueología 5:207-22. http://dx.doi.org/10.5944/etfi.5.2012.9274 
Whallon, Robert. 2006. Social networks and information: Non-'utilitarian' mobility among hunter-gatherers. Journal of Anthropological Archaeology 25(2):259-70. http://dx.doi.org/10.1016/j.jaa.2005.11.004

Wobst, H. M. 1974. Boundary conditions for Paleolithic social systems: A simulation approach. American Antiquity 39(2):147-78. http://dx.doi.org/10.2307/279579

Zilhão, João. 1997. O Paleolítico Superior da Estremadura Portuguesa. Lisboa: Edições Colibri.

Zilhão, João, ed. 1997. Arte rupestre e pré-história do Vale do Côa: Trabalhos de 1995-1996. Lisboa: Ministério da Cultura.

Zilhão, J., D. Angelucci, T. Aubry, E. Badal, J.P. Brugal, R. Carvalho, C. Gameiro, D. Hoffmann, H. Matias, J. Maurício, M. Nabais, A. Pike, L. Póvoas, D. Richter, P. Souto, E. Trinkaus, K. Wainer, and J. Willman. 2013. "A gruta da Oliveira (Torres Novas): Uma jazida de referência para o Paleolítico Médio da Península Ibérica," in Arqueologia em Portugal - 150 anos, pp. 259-68. Lisboa: Associação Portuguesa dos Arqueológos Portugueses. 